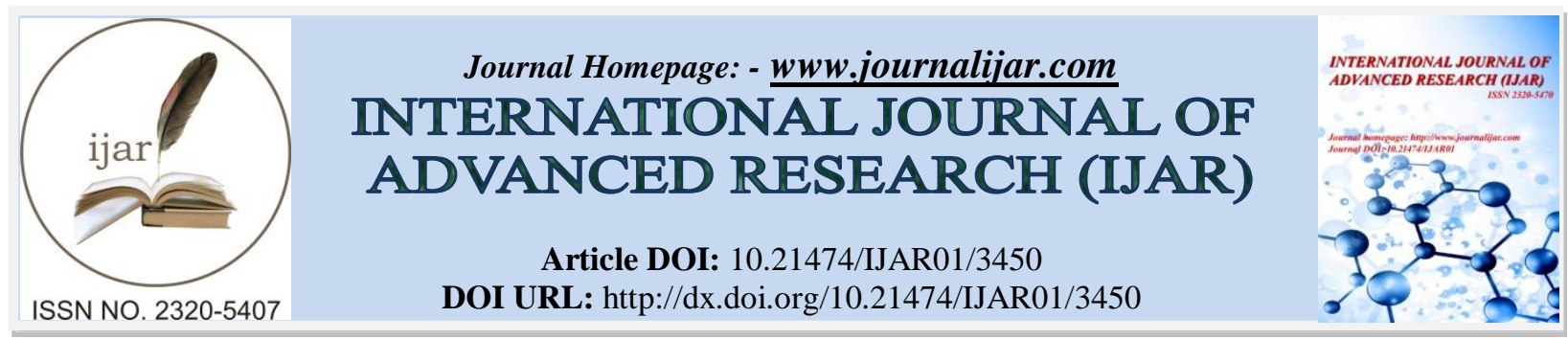

RESEARCH ARTICLE

\title{
STUDY OF COUPLE'S AWARENESS ABOUT THE RELATIONSHIP BETWEEN STREP THROAT AND RHEUMATIC FEVER IN THE WESTERN AREA OF THE KINGDOM OF SAUDI ARABIA.
}

\section{Dr. Mohammed Ateih Awwad Alsofyani, Dr. Maryam Hussain Ali Alessa, Dr. Hassan Ahmed Alsahaf and Dr. Malak Fahad Almogthali.}

\section{Manuscript Info}

Manuscript History

Received: 27 December 2016

Final Accepted: 10 January 2017

Published: February 2017

\section{Abstract}

Objectives: The aim of the study to assess the family habit and status related to the factors associated with the development of the rhemautic fever and be aware about it.

Methods: The Type Of The Study Is Cross Sectional, It Will Include Collection Of Data From The Community's To Measure Their Awareness About Sore Throat And Its Relation To Rheumatic Fever. The Data Will Be Collected In The Western Area Of Kingdom Of Saudi Arabia, By Distributing A Form To The Families Which Included Questions About The Awareness Based On The Literature Review.

Results: This Study Was Applied On (407) Husbands And WivesFrom Different Cities In Western Area Of Kingdom Of Saudi Arabia. .Most Of Them Were Female 260 (63.9 \%) And 147 (36.1) Were Male.

Conclusion: We Conclude That The Parent Who Lived In The Eastern Region Of Saudi Arabia Need To Be More Educated Regarding The Sore Throat And Its Complication To Reduce The Incidence In The Future. This Could Be Done By Conducting Many Voluntarily Campaigns To The Family, Educative Accounts In The Social Media, Distribution Of Leaflet To The Parents.

Copy Right, IJAR, 2017,. All rights reserved.

\section{Introduction:-}

A Sore Throat Is Frequently The Primary Indication Of A Cold. In Any Case, A Sore Throat Usually Improves Or Cures After A Day Or Two. Other Cold Manifestations, For Example, A Runny Nose And Clog May Take After The Sore Throat. Strep Throat, Which Is A Contamination Because Of Streptococcus Microorganisms, Is Another Reason For Sore Throats And Tonsillitis. With Strep Throat, The Sore Throat Is More Serious. (1)

In United States The Frequency Of An Intense Rheumatic Scene Taking After Streptococcal Pharyngitis Is 0.5-3\% . (2)

Acute Rheumatic Fever (ARF) And Its Sequelae Remain The Leading Cause Of Cardiovascular Disease In Children And Young Adults Especially In Developing Countries. It Represents A Major Public Health Problem Causing A Lot Of Suffering To The Patient And Their Families.(3) 
In Western Locale In Saudi Arabia Rheumatic Heart Disease Was 24 For Every 10,000 Schoolchildren (6-15 Years) Higher In Country Ranges And In Females And 34\% Is The Bearer Rate Of Beta-Hemolytic Streptococci. (2) Around The World, Rheumatic Heart Disease (Rhd) And Its Confusions Result In Around 233000 Passings Every Year. The World Wellbeing Association (Who) Appraises That Around 16 Million Individuals Are At Present Influenced By The Disease. The Dominant Part Of Rhd Cases Happen In Africa Where Commonness Rates Are As High As One In 10 Individuals In A Few Groups. (4)

Consistently, Around 15 Million Individuals Are Influenced, 200,000 Bite The Dust, And 100,000 Get To Be Disabled.(5)

We Have Proven From Past And Current Activities, Founded In Different Parts Of The World, That Far Reaching Programs Joining Mindfulness Raising, Observation, And Anticipation Can Control RHD As Well As Make A Worldwide RHD Plan And Develop A Stage For Cooperation. (6)

Starting Here, We Do A Poll To Assess Awareness About Rheumatic Fever To Know Degree Of Awareness In Group As A First Study In Kingdom Of Saudi Arabia Done To Know The Couple's Awareness About Rheumatic Fever.

\section{Methodology:-}

The Type Of The Study Is Cross Sectional, It Will Include Collection Of Data From The Community's To Measure Their Awareness About Sore Throat And Its Relation To Rheumatic Fever.

The Data Will Be Collected In The Western Area Of Kingdom Of Saudi Arabia, By Distributing A Form To The Families Which Included Questions About The Awareness Based On The Literature Review And Who Recommendation.

The Questions Include Ages, Number Of Children, City, Financial Status, And General Information About The Disease.

The Ethical Approval Will Be From The Research Committee In The College Of Medicine, Taif University.

\section{Results:-}

The Aim Of The Study To Assess The Couple's Awareness About Sore Throat And Its Relation To Rheumatic Fever. This Study Was Applied On (407) Husbands And WivesFrom Different Cities In Western Area Of Kingdom Of Saudi Arabia. ( Table 1 ) .Most Of Them Were Female 260 (63.9 \%) And 147 (36.1) Were Male (Graph 1). The Age Of The Studied Group Was Above 18 Years ( Distribution Of Age Will Be Shown On The Graph Below ( Graph 2 ).

Education Level Of The Studied Group Is Shown On Table (2) 71.5\% (291) Of The Studied Group Were Having University Or Higher Education, 22.4\% (91) Were HavingSecondary School Education, 4.2\% (17) Were Having Intermediate School Education, While 2.0\% (8) Were HavingPrimary School Education. Works Areas Of The Studied Group Were 37\%(151) Were Not Working, 33\% (133) Were In Educational Field, 13\% (52) Were Health Care Workers , 8\% (34) Were In Army Field , 7\% (27) Were Private Sector And 2\% (10) Were General Work Or Business(Graph 3 ).

Monthly Income Of The Studied Group Is Shown On Table (3) 45.2\% (184) Were More Than 10000 SR, 27.8\% (113) Were 5000-10000 SR , 19.2\% (78) Were Between 2000-5000 SR, 7.9\% (32) Were Less Than 2000 Sr. 88.5\% (360) Of All Studied Group Had Children While 11.5\% (47) Did Not Have Children (Graph 4). 38.33\% (156) Of All Studied Group Had More Than Three Children, 19.17\% (78) Had One Child, 15.72\% (64) Had Three Children While 15.32\% (62) Had Two Children (Graph 5).

86.4\% (352) Have The Children Previously Had Sore Throat While 13.6\% (55) Did Not Have (Graph 6). 71.7\% (292) Of All Studied Group Went To A Doctor To Treat His/hers Infected Child With Sore Throat, 9.34\% (38) Did Not Do Anything And 5.4\% (22) Home Remedies (Graph 7). 86.2\% (351) Of All Studied Group Had An Infected Child With Sore Throat While 13.8\% (56) Did Not Have An Infected Child With Sore Throat (Graph 8). 31.2\% 
(127) ) Of The Studied Group Were Believe That The Cause Of Sore Throat Is Virus , 11.5 (47) They Did Not Know, 10.1\% (41) Bacteria, 2.9\% (12) Dry Throat, $2.7 \%$ (11) Allergy, $0.2 \%$ (1) Gastroesophageal Reflex Disease, 0.5 (2) Tumors, 33.2\% (135) Some Of Them While 7.6\% (31) Were Believe All Of Them Can Cause The Sore Throat (Graph 9). 33.9\% (138) Were Believe That There Is A Relationship Between Sore Throat And Some Heart Diseases, 14.3\% (58) Were Believe That There Is No Relationship Between Sore Throat And Some Heart Diseases While 51.8\% (211) They Did Not Know (Graph 10).

45.5\% (185) Of All Studied Group Were Think That The Best Treatment For Sore Throat Has A Relationship To Prevent Heart Disease, 6.1\% (25) Think That The Best Treatment For Sore Throat Has No A Relationship To Prevent Heart Disease While 48.4\% (197) They Did Not Know (Graph 11 ) . 15.5\% (63) Of All Studied Group Had Family Member Or Friend Diagnosed With Rheumatic Fever While 84.5\% (344) Did Not Have (Graph 12 ). 45.7\% (186) Of All Studied Group Believe That The Age From 5 To 15 Years OldAre More Affected Of Rheumatic Fever, 21.6\% (88) Believe That The Age More Than 36 Years Old Are More Affected, 17.2\% (70) Less Than 5 Years And 15.5\% (63) Believe That The Age From 16 To 35 Years Old Are More Affected (Graph 13). 14.0\% (57) Of All Studied Group Think That Fever, Pain In The Joints, Involuntary Movements, Rash On The Body, Protrusions In The SkinAre Signs Some Of Heart Disease, 15.7\% ( 64) Did Not Think, 70.3\% (286) They Did Not Know (Graph 14 ). 16.7\% (68) Of All Studied Group Were Know That To Treatment A Patient Who Had A Rheumatic Fever, Has To Follow A Course Of Antibiotic (Mostly By Injections) For A Five To Ten Years Old If His Case Affecting The Heart While 83.3\% (339) They Did Not Know (Table 4).

Table (1 ):- The Cities Of The Studied Group

\begin{tabular}{|l|l|l|}
\hline City & Frequency & Percent \\
\hline Jeddah & 129 & 31.7 \\
\hline Laith & 4 & 1.0 \\
\hline Makkah & 57 & 14.0 \\
\hline Qanfatha & 5 & 1.2 \\
\hline Rabig & 3 & .7 \\
\hline Taif & 209 & 51.4 \\
\hline
\end{tabular}

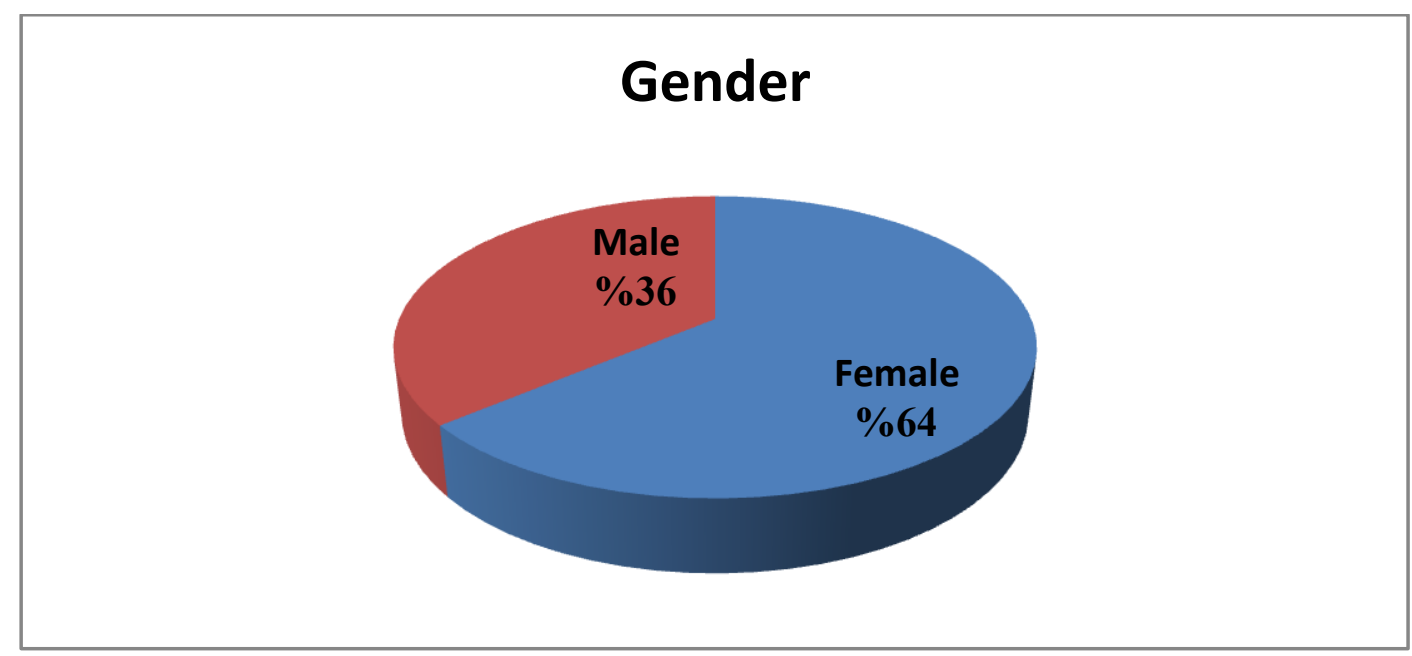

The Graph (1):- Show The Gender Distribution Of The Studied Group : 260 (63.9\%) Were Females And And147 (36.1) Were Males 


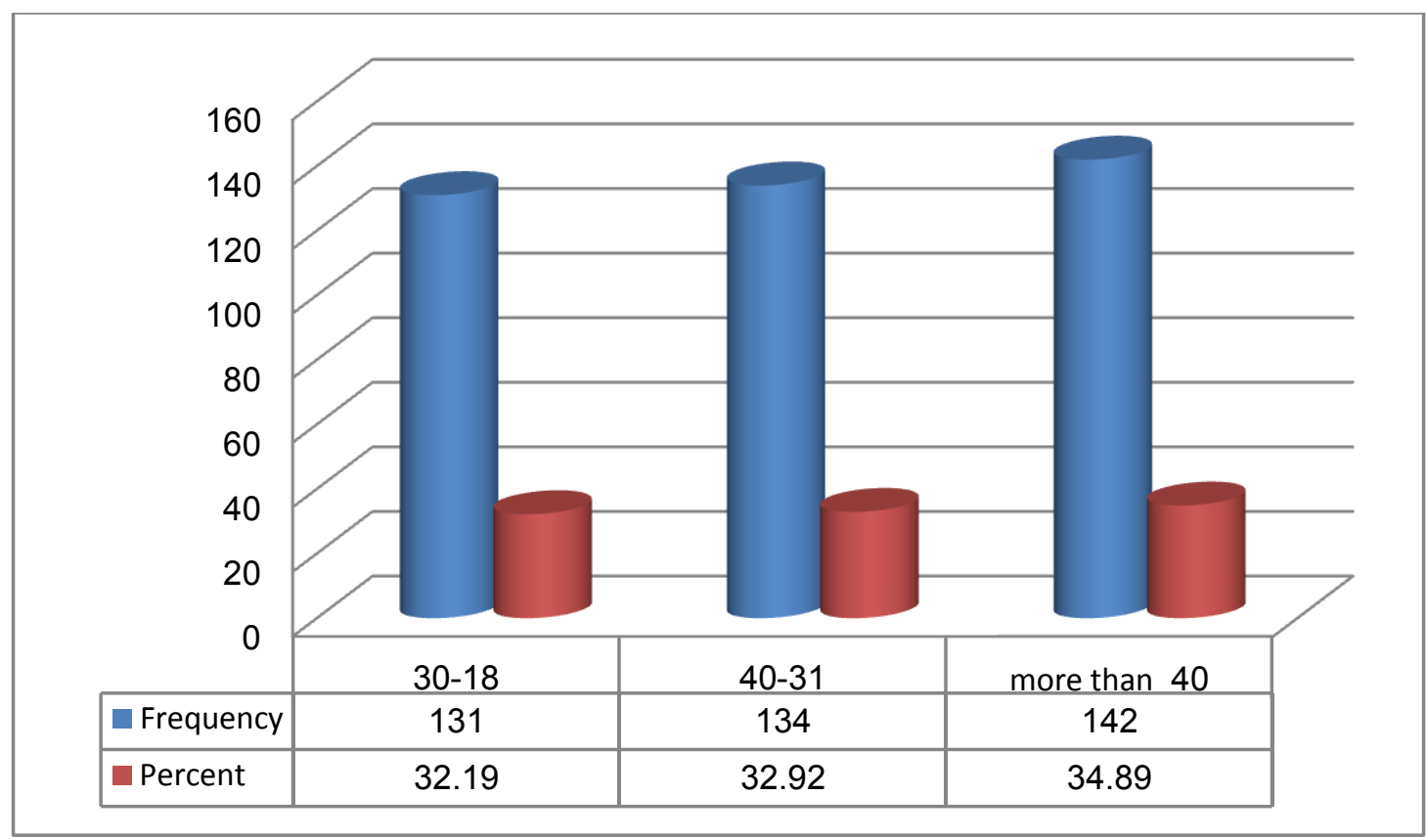

The Graph (2):- Show The Age Distribution Of The Studied Group.

Table (2):- Education Level Of The Studied Group Is Shown On.

\begin{tabular}{|l|l|l|}
\hline Education Level & Frequency & Percent \\
\hline Intermediate School & 17 & 4.2 \\
\hline Primary School & 8 & 2.0 \\
\hline Secondary School & 91 & 22.4 \\
\hline University Or Higher Studies & 291 & 71.5 \\
\hline
\end{tabular}

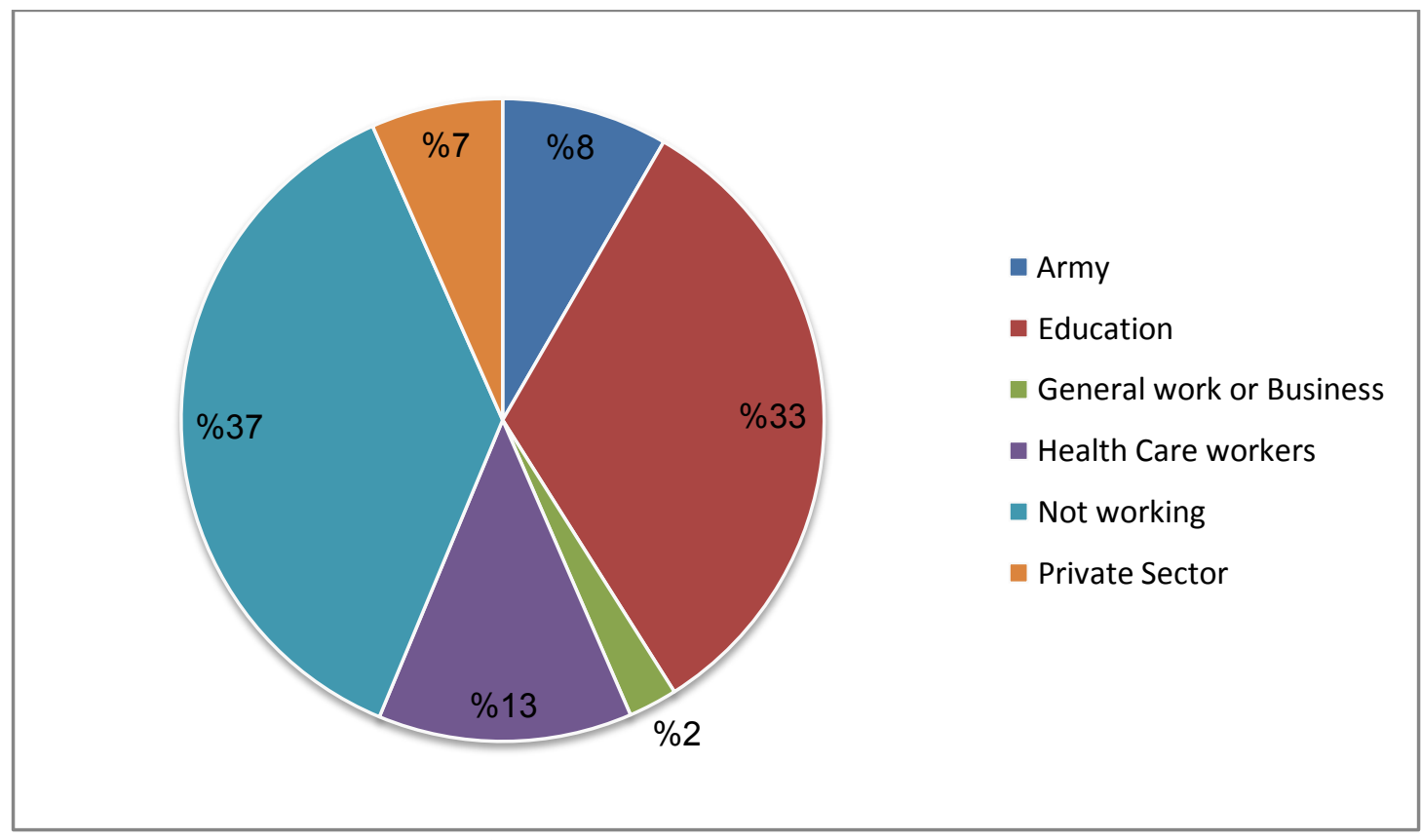

The Graph (3):- ShowWorks Areas Of The Studied Group. 
Table (3):- Monthly Income Of The Studied Group.

\begin{tabular}{|l|l|l|}
\hline Monthly Income & Frequency & Percent \\
\hline Less Than 2000 & 32 & 7.9 \\
\hline $2000-5000$ & 78 & 19.2 \\
\hline $5000-10000$ & 113 & 27.8 \\
\hline More Than 10000 & 184 & 45.2 \\
\hline
\end{tabular}

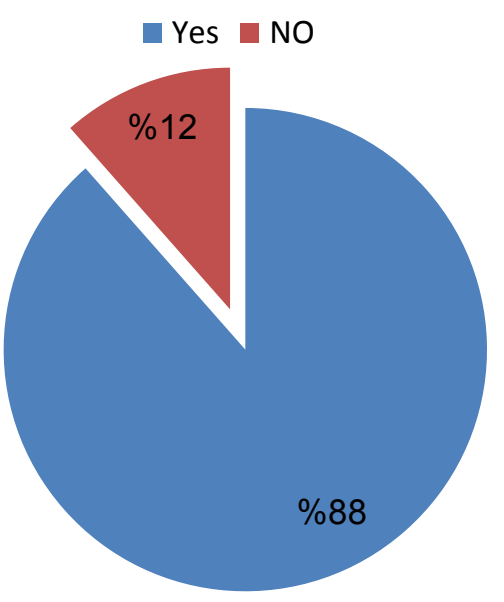

The Graph (4):- Showing The Percentage Of Couples Have Children In The Studied Group.

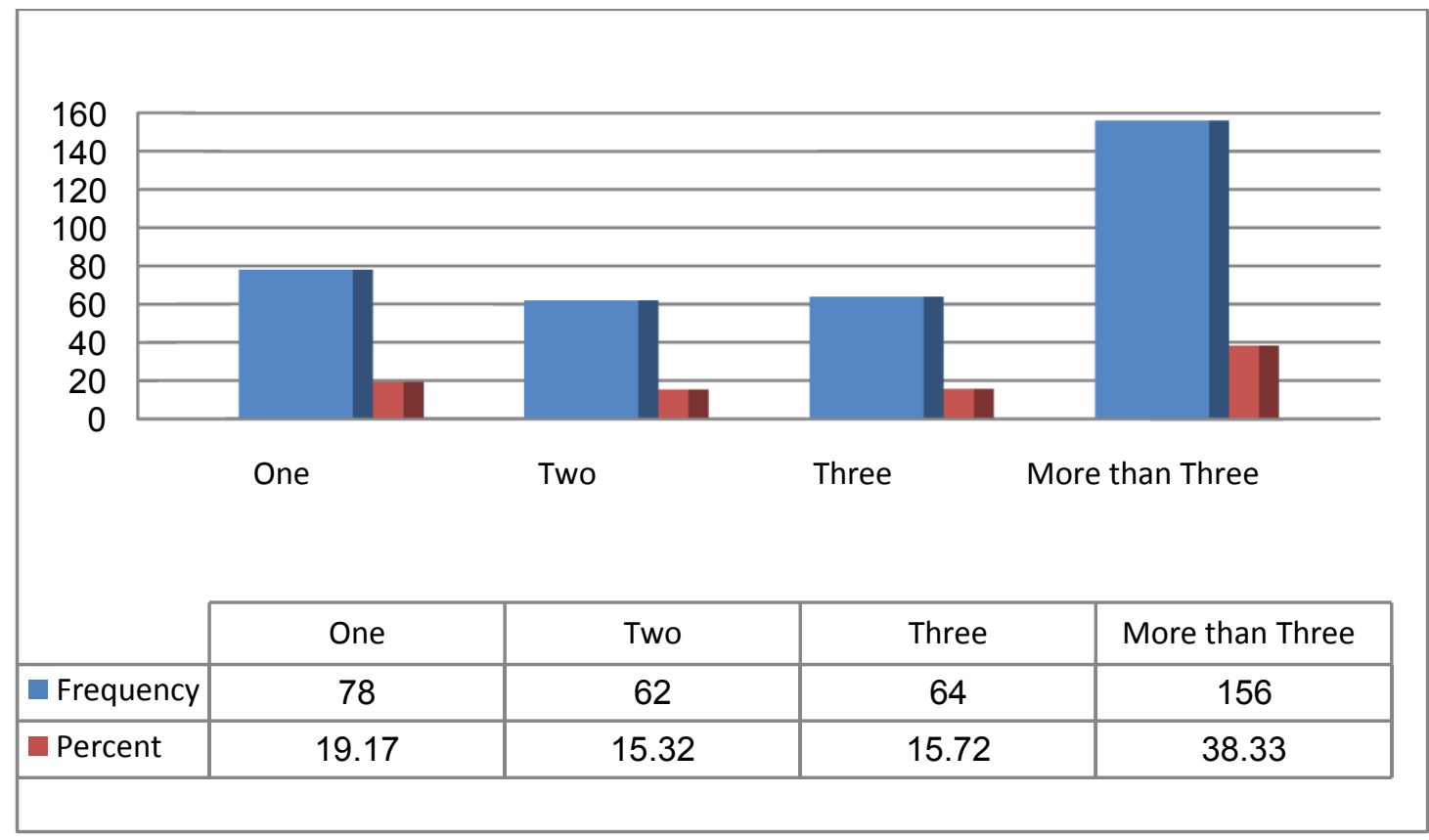

(Graph 5):- Show The Number Of Children Of The Studied Group 


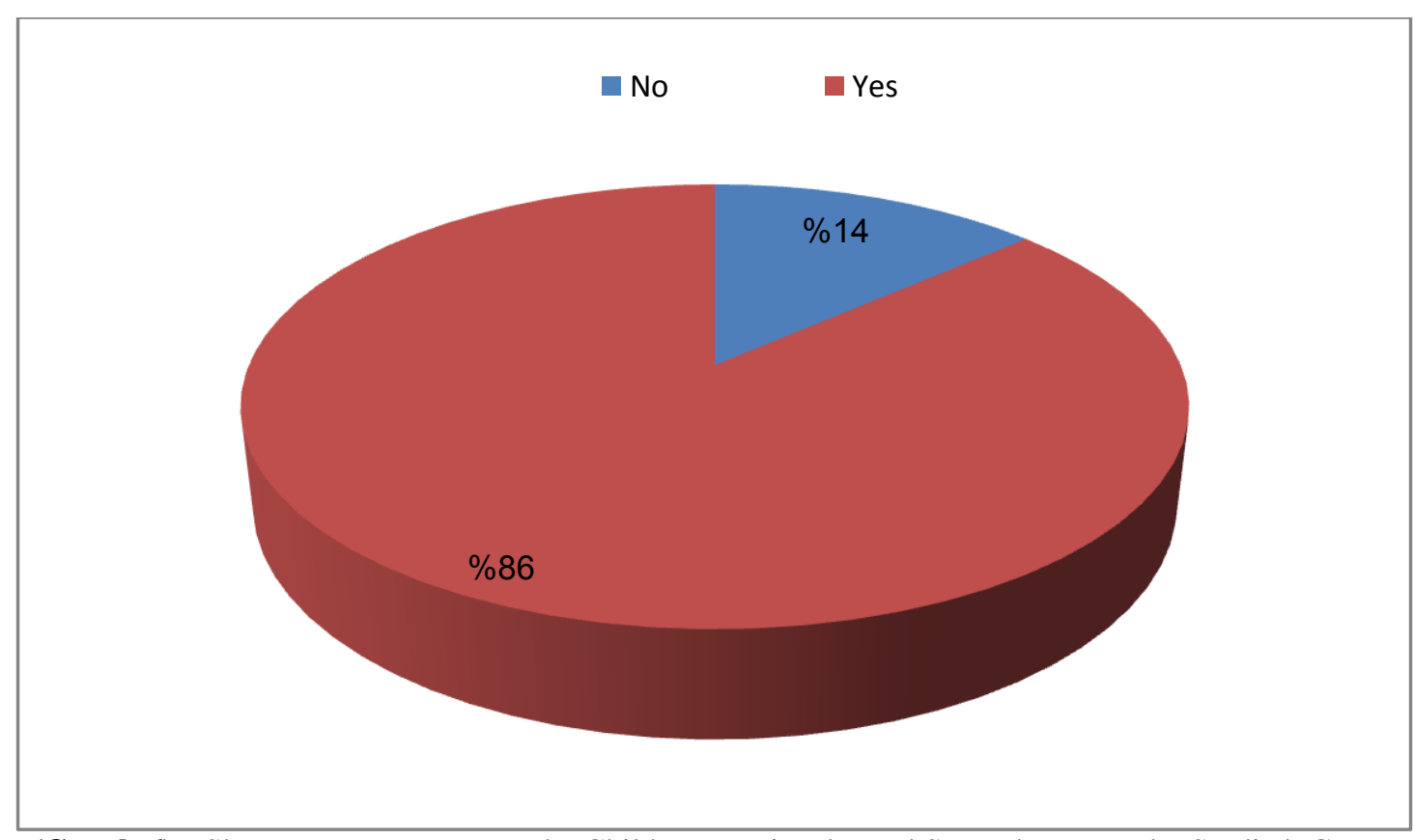

(Graph 6):- Show Percentage Have The Children Previously Had Sore Throat In The Studied Group.

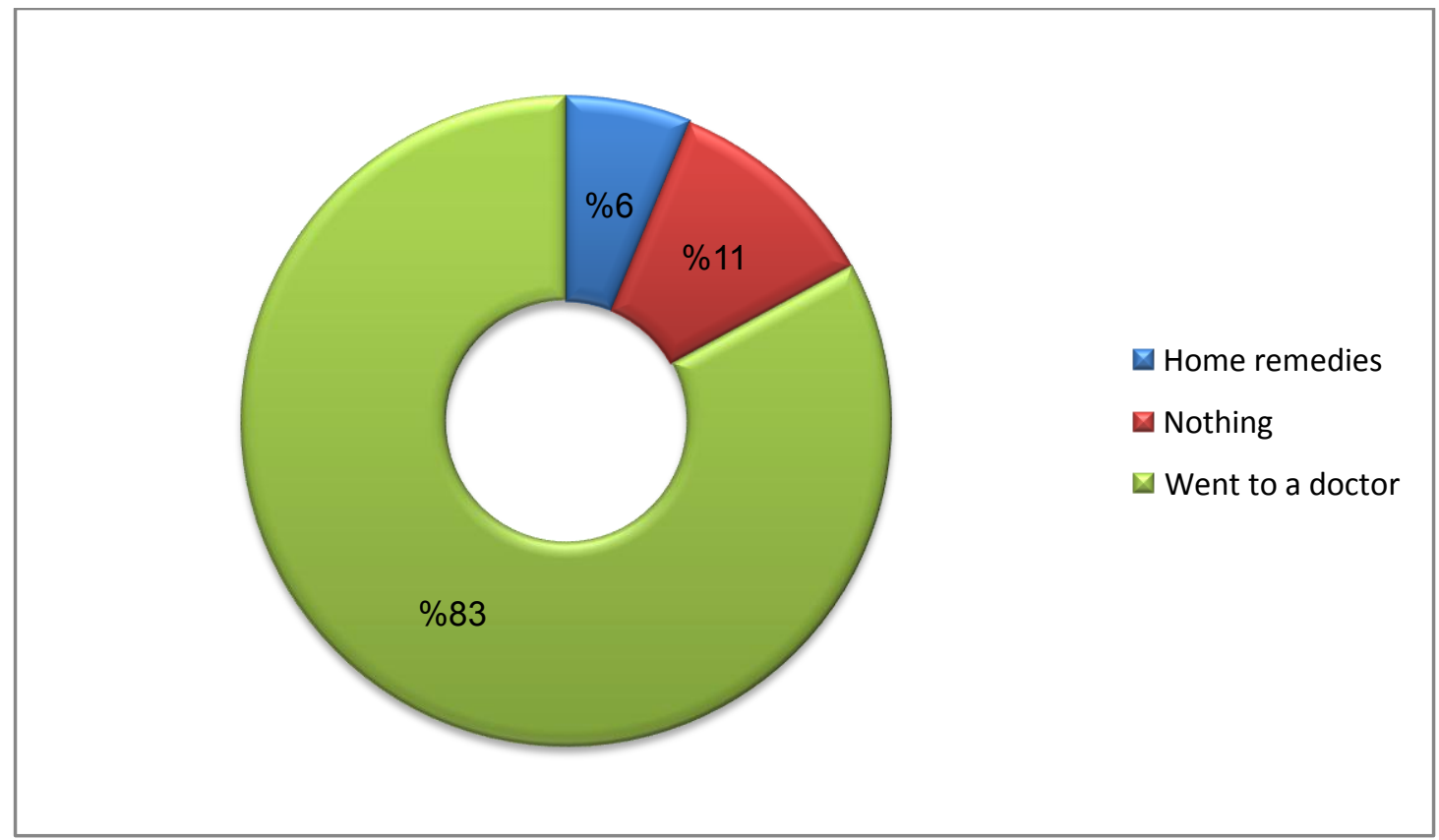

(Graph 7):- Show What To Did To Treatment Of Sore Throat In The Studied Group. 


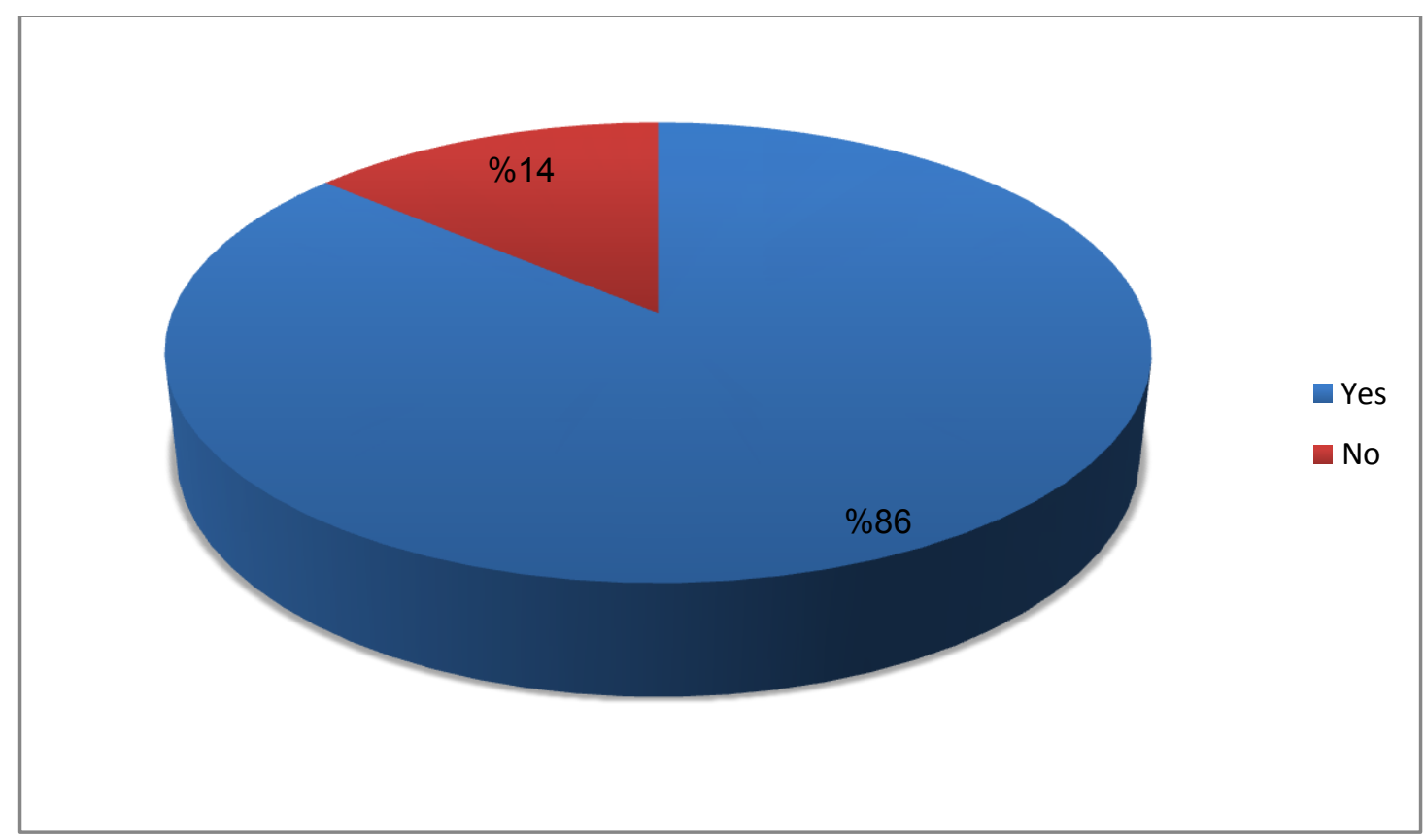

The Graph (8):- Showing The Percentage Of Couples Have Had An Infected Child With Sore Throat In The Studied Group.

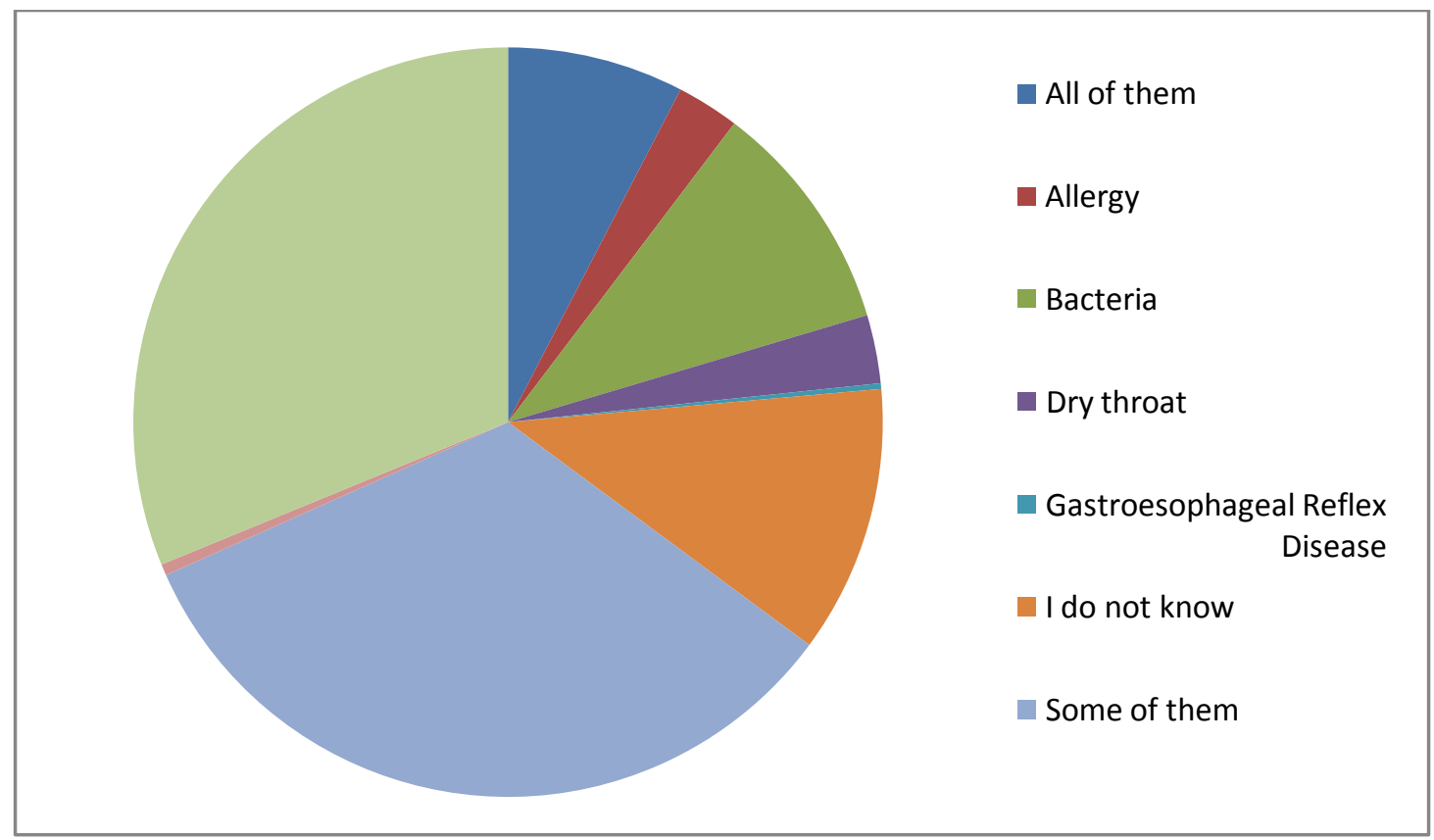

The Graph (9):- Showing The Causes Of Sore Throat That The Studied Group Believe 


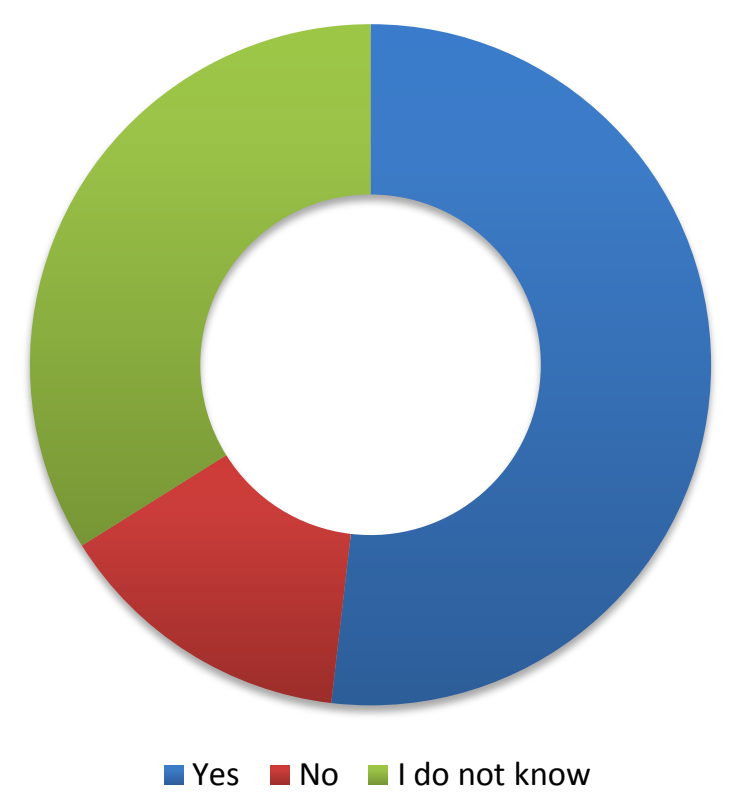

The Graph (10):- Show The Best Treatment For Sore Throat Relationship To Prevent Heart Disease In The Studied Group.

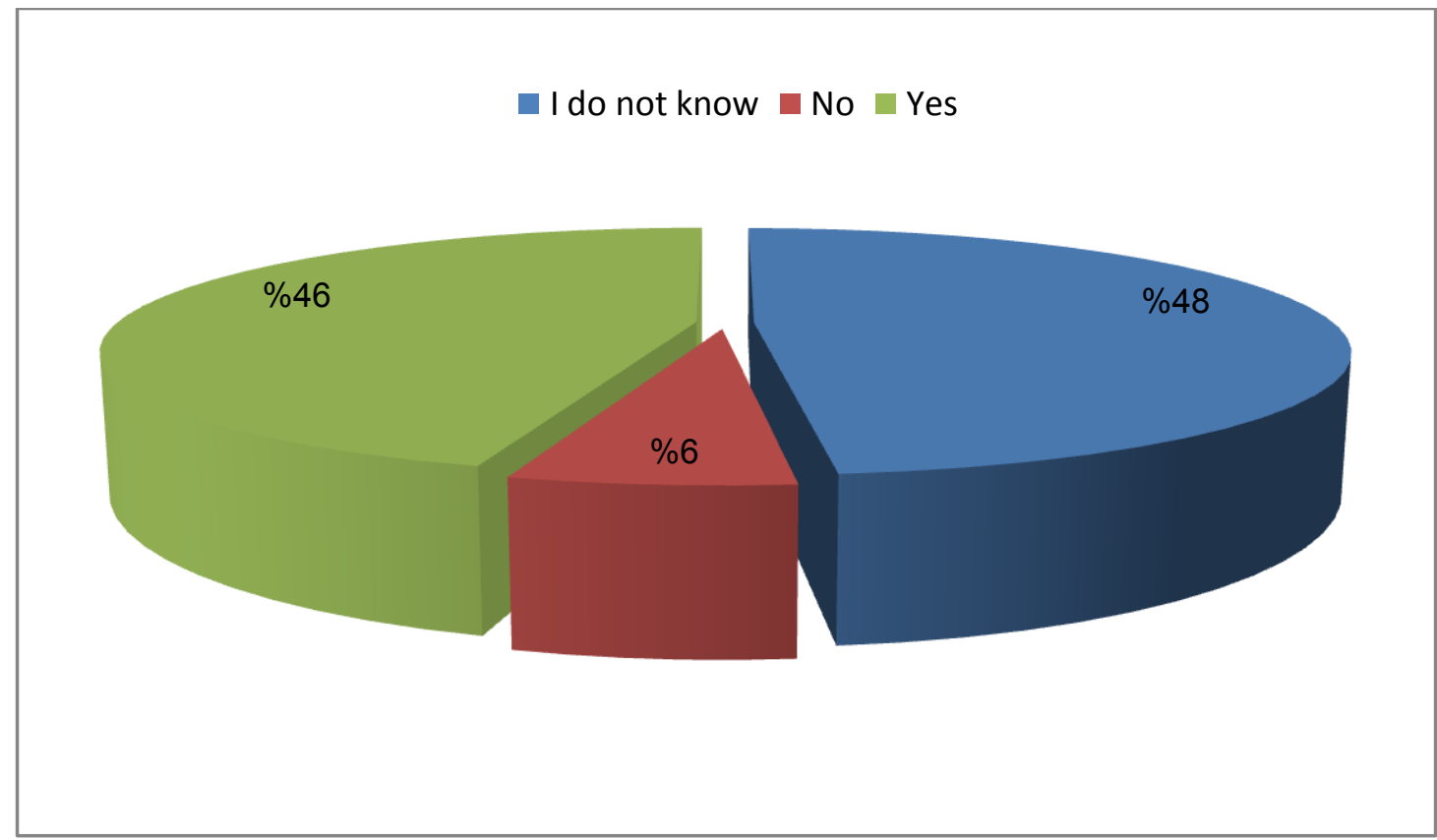

Graph (11):- Show The Think Of The Studied Group. 


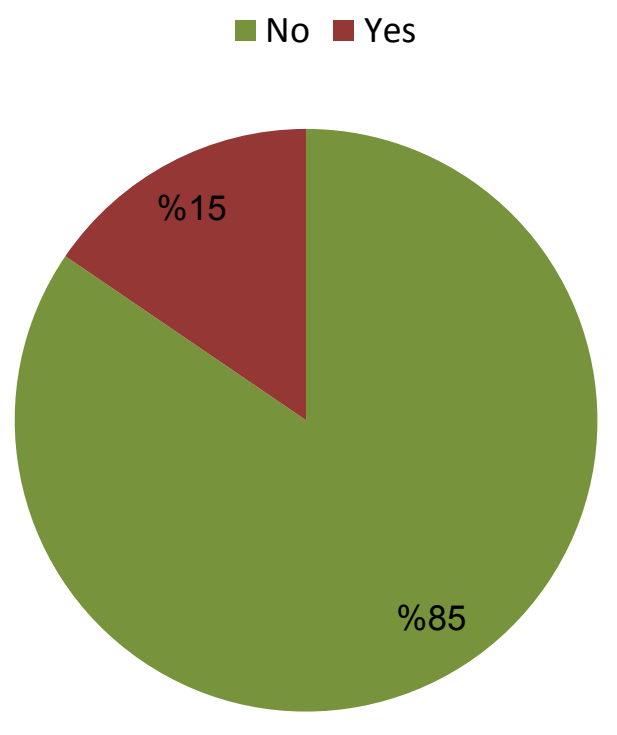

(Graph 12):- Show Family Member Or Friend Diagnosed With Rheumatic Fever In The Studied Group

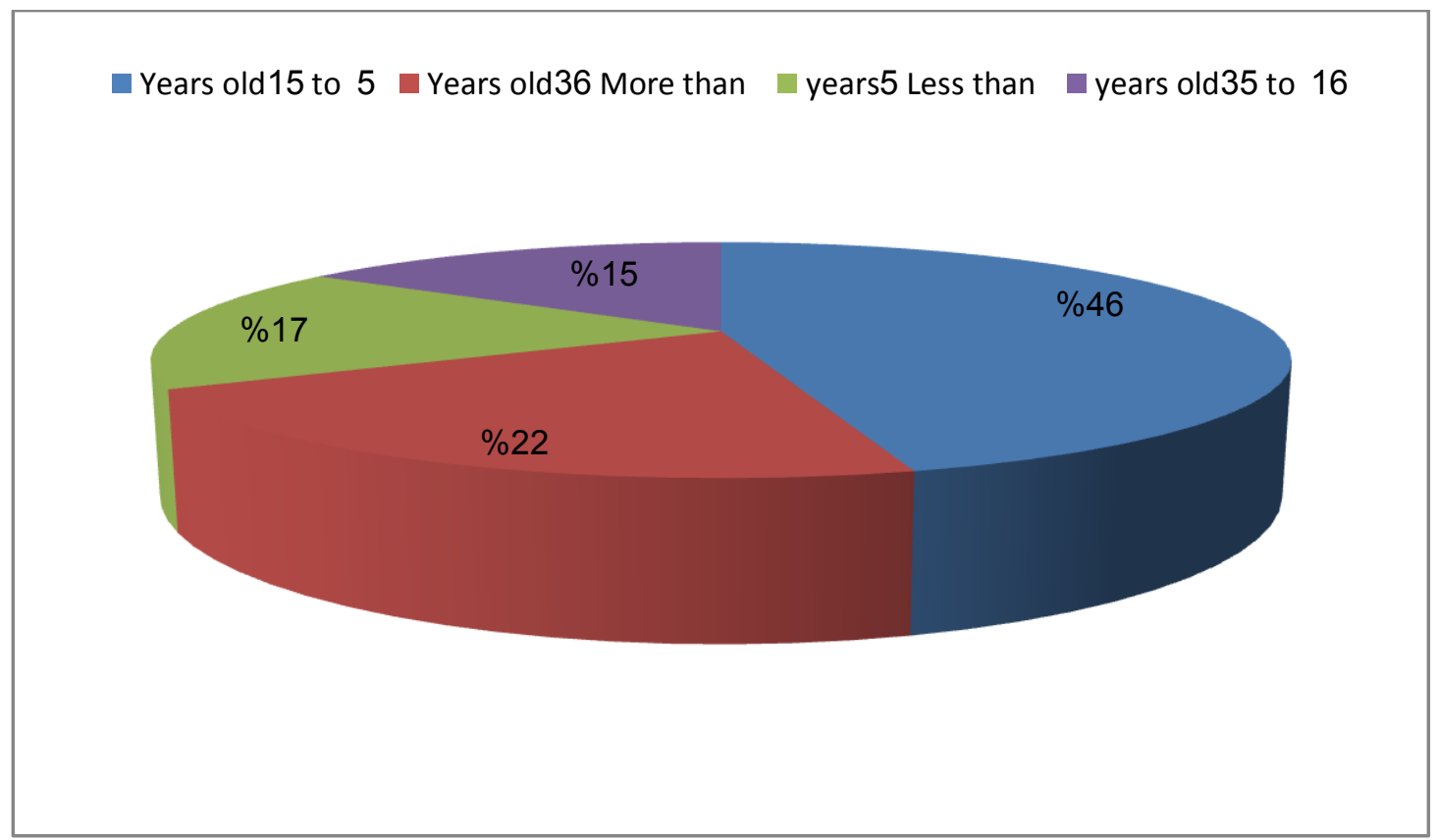

(Graph 13):- Group Of Ages Are More Affected Of Rheumatic Fever In Believe Studied Group 


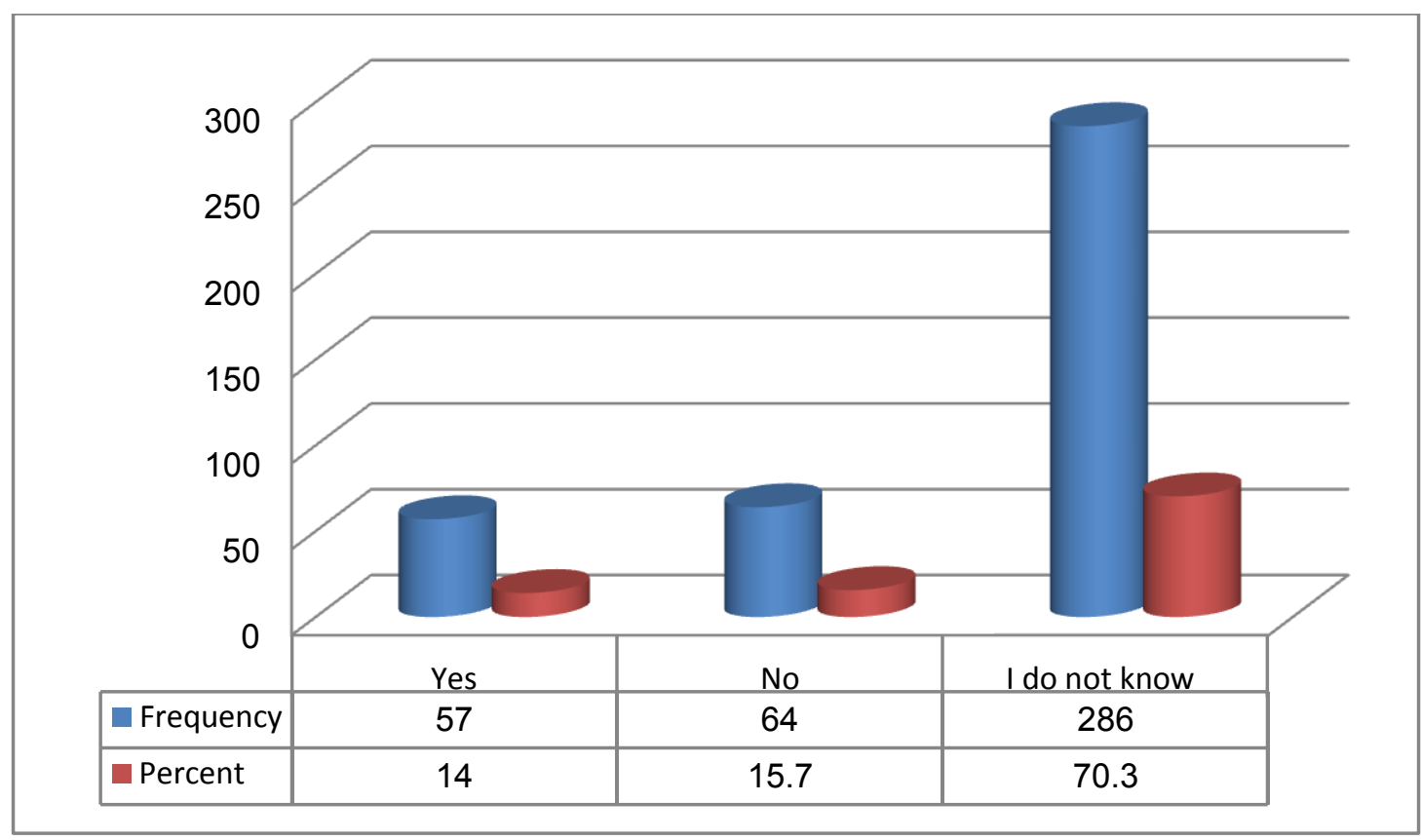

(Graph 14):- Show The Think Of The Studied Group About The Some Signs Of Heart Disease.

Table (4):- Treatment A Patient Who Had A Rheumatic Fever Affecting The Heart With Antibiotic.

\begin{tabular}{|l|l|l|}
\hline Treatment With Antibiotic & Frequency & Percent \\
\hline No & 339 & 83.3 \\
\hline Yes & 68 & 16.7 \\
\hline
\end{tabular}

\section{Discussion:-}

Confusions Of Strep Throat Are Uncommon Yet Can Happen, Particularly If Strep Throat Is Not Appropriately Treated With Antibiotics Now And Again Because Of A Strep Disease, The Body's Safe Framework Will Assault Solid Tissues, Bringing About Complexities, For Example, Rheumatic Fever.(7)

Rheumatic Fever Can Bring About Long Haul Confusions In Specific Circumstances. A Standout Amongst The Most Common Confusions Is Rheumatic Coronary Illness. Kids Who Experience The Ill Effects Of Long Haul Harm Identified With Rheumatic Fever Might Be Qualified For A Specialized Curriculum And Other Related Administrations.(8)

The Quality Of Our Review Is The Main Overview In The Kingdom Of Saudi Arabia Do To Know The Couple's Mindfulness About Rheumatic Fever, In Our Insight .

Constraints In Our Review Incorporate Utilization Of An Online Overview That May Prompt To Determination Inclination And Not All Couples Can Be Utilize Web. Consequently, We Couldn't Sum Up Our Discoveries To All Couple's .

\section{Conclusion:-}

We Conclude That The Parent Who Lived In The Eastern Region Of Saudi Arabia Need To Be More Educated Regarding The Sore Throat And Its Complication To Reduce The Incidence In The Future. This Could Be Done By Conducting Many Voluntarily Campaigns To The Family, Educative Accounts In The Social Media, Distribution Of Leaflet To The Parents.

\section{Acknowledgment:-}

We are a group of doctors from different cities who shared together in finishing this research under supervision of Dr. Mamdouh Ari Nasser Alshareef hoping that it will be benefit in the medical field.

Dr. Mohammed Ateih Awwad Alsofyani, Dr. Maryam Hussain Ali Alessa, Dr. Hassan Ahmed Alsahaf and Dr. Malak Fahad Almogthali. 


\section{References:-}

1. Nl, S. (2017). Acute Tonsillitis. - Pubmed - Ncbi. [Online] Ncbi.Nlm.Nih.Gov. Available At: Https://Www.Ncbi.Nlm.Nih.Gov/Pubmed/22338587 [Accessed 18 Jan. 2017].

2. Emedicine.Medscape.Com. (2017). Acute Rheumatic Fever: Background, Pathophysiology, Etiology. [Online] Available At: Http://Emedicine.Medscape.Com/Article/333103-Overview\#A7 [Accessed 18 Jan. 2017].

3. Globalheart-Journal.Com. (2017). Cite A Website - Cite This For Me. [Online] Available At: Http://Www.Globalheart-Journal.Com/Article/S2211-8160(13)00115-4/Abstract?Cc=Y [Accessed 15 Jan. 2017].

4. Emmy Okello, R. (2013). Cardiovascular Complications In Newly Diagnosed Rheumatic Heart Disease Patients AtMulago Hospital, Uganda. Cardiovascular Journal Of Africa, [Online] 24(3), P.82. Available At: Http://Pubmedcentralcanada.Ca/Pmcc/Articles/Pmc3721959/ [Accessed 2 Sep. 2016].

5. Do NascimentoMoraes, A., Ramos AscensãoTerreri, M., EstevesHilário, M. And Len, C. (2017). Health Related Quality Of Life Of Children With Rheumatic Heart Diseases: Reliability Of The Brazilian Version Of The Pediatric Quality Of Life Inventory ${ }^{\mathrm{TM}}$ Cardiac Module Scale.

6. Globalheart-Journal.Com. (2017). Cite A Website - Cite This For Me. [Online] Available At: Http://Www.Globalheart-Journal.Com/Article/S2211-8160(13)00115-4/Abstract?Cc=Y [Accessed 18 Jan. 2017].

7. Cold, F., Health, E., Disease, H., Management, P., Conditions, S., Problems, S., Disorders, S., Checker, S., Interviews, E., Boards, M., Guide, I., Doctor, F., Medications, M., Identifier, P., Interactions, C., Drugs, C., Pregnant, T., Management, D., Obesity, W., Recipes, F., Exercise, F., Beauty, H., Balance, H., Relationships, S., Care, O., Health, W., Health, M., Well, A., Teens, H., Kids, F., Pregnant, G., Trimester, F., Trimester, S., Trimester, T., Baby, N., Health, C., Vaccines, C., Kids, R., Cats, H., Dogs, H., Fillings?, C., Sushi, T., Earwax, D., Knees?, I., Stroke, V., Boards, M., Blogs, E., Center, N. And Care, O. (2017). Strep Throat ComplicationsTopic Overview. [Online] Webmd. Available At: Http://Www.Webmd.Com/Oral-Health/Tc/Strep-ThroatComplications-Topic-Overview [Accessed 18 Jan. 2017].

8. Healthline. (2017). Rheumatic Fever. [Online] Available At: Http://Www.Healthline.Com/Health/RheumaticFever\#Complications8 [Accessed 18 Jan. 2017]. 